Jan Romuald Olędzki

\title{
GEOINFORMATICS - AN INTEGRATED SPATIAL RESEARCH TOOL
}

\begin{abstract}
The structure of geoinformatics can be understood in many ways, what can be seen from the more or the less complex schemas published in various articles. Geoinformatics creates new possibilities for the precise analysis of spatial phenomena, such as for following their dynamics or defining the associations existing between their components. The use of remote sensing data in such research, takes to another level those areas of knowledge, in which there nevertheless still is a scarcity of reliable materials. It also enables the current monitoring of those phenomena which can't be investigated and estimated in any other way, as well as the modeling of spatial (geographical) phenomena. Since 1996, many studies have been performed at the Laboratory of Remote Sensing of the Environment at the University of Warsaw, in which remote sensing data were integrated with data obtained by other means.
\end{abstract}

Key words: geoinformatics, remote sensing, geography.

The era of using satellites to study the surface of the Earth began in the late 1950s. From the moment of the launching of the first artificial satellite, there was a marked increase in the amount of information regarding the Earth, obtained with the help of satellites. This increase was significantly tied to the development of space technology.

As it is well known, the amount of data concerning the Earth soared, following 1972, when the first operational satellite was put in orbit; its purpose being to constantly provide comparable data regarding land surface, on a global scale. The satellite, initially called ERTS-1, was soon renamed LANDSAT, due to the launching of an entire series of such satellites within the framework of a research program in land remote sensing, and the development of other satellites - SEASAT - in the preparation for an oceanographic remote sensing research program. To be able to conceptualize the increase in the amount of spectral data supplied by the most popular satellite systems, one could imagine for instance that 1 pixel $=1$ unit of data, and while the MSS scanner supplies 641 data units per $1 \mathrm{~km}^{2}$, the TM scanner supplies 6,736 data units and IKONOS supplies 1,250,000 units of spectral data.

The increase in the diversity of spectral data could be illustrated by the widening of the spectrum of electromagnetic radiation registered, and the increase in the number of spectral bands that various types of imaging devices were and are equipped with (Table 1 ). 
Spectral sensitivity and the number of spectral bands for each of the different satellite imaging systems

\begin{tabular}{|c|c|c|}
\hline Satellites & Spectral sensitivity & Number of spectral bands \\
\hline LANDSAT $-1(1972)$ & $0.4-1.1 \mu \mathrm{m}$ & RBV -3 MSS -4 \\
\hline LANDSAT $-7(1999)$ & $0.45-12.50 \mu \mathrm{m}$ & ETM+ -7 \\
\hline SEASAT (1978) & $23.5 \mathrm{~cm}$ & 1 \\
\hline ERS - 2 (1995) & $5.56 \mathrm{~cm}$ & 1 \\
\hline RADARSAT (1995) & $5.56 \mathrm{~cm}$ & 10 \\
\hline EO - 1 (NOV. 21, 2000) & $0.433-2.35 \mu \mathrm{m}$ \\
ALI & $0.36-2.6 \mu \mathrm{m}$ & 220 \\
\hline HYPERION & &
\end{tabular}

The radiometric resolution of satellite image data has increased considerably. Data from the MSS scanner on LANDSAT-1 were coded in a 6-bit system, what gave 64 gray levels per pixel; for TM scanners (LANDSAT-4 and 5) the coding was 8-bit, giving 256 grey levels; for ETM+ (LANDSAT-7) the coding is 9-bit, what gives 512 grey levels. Data from the panchromatic band of IKONOS are coded in an 11-bit system, what gives 2,048 grey levels (Fig. 1).

Also worth noting is the increasing frequency with which, within the nadir observation system, the same locations can be repeatedly registered by satellites equipped with spatially high- and mid-resolution scanning systems. And so, within a year, LANDSAT- $1(1972)^{1}$ could pass over the same region 20 times; LANDSAT-7 (1999) - 23 times; IKONOS (1999) - 33 times. The diagram shows the frequency of the satellites' revisitation. With movable mirrors and oblique observation, the recurrence rate increases manyfold.

The amount of data obtained with regard to different aspects of the environment has soared as the result. It is difficult to imagine interpreting these data by simple visual methods. One should also account for the rise in environment-related information obtained by other, satellite-aided geodetic (GPS); cartographic; and statistical methods. This enormous amount of information calls for new methods of data management, processing and dissemination. This is where the need is met by the equally dynamic development of computer hardware and software. The data are not only disseminated in their traditional cartographic form, but also in other multi-dimensional forms dynamic animated images and various sorts of databases that combine spatial information about various aspects of the environment. This creates not only the opportunity for presenting various spatial events in a new way, but

1 The year in which the satellite was placed in the Earth's orbit. 


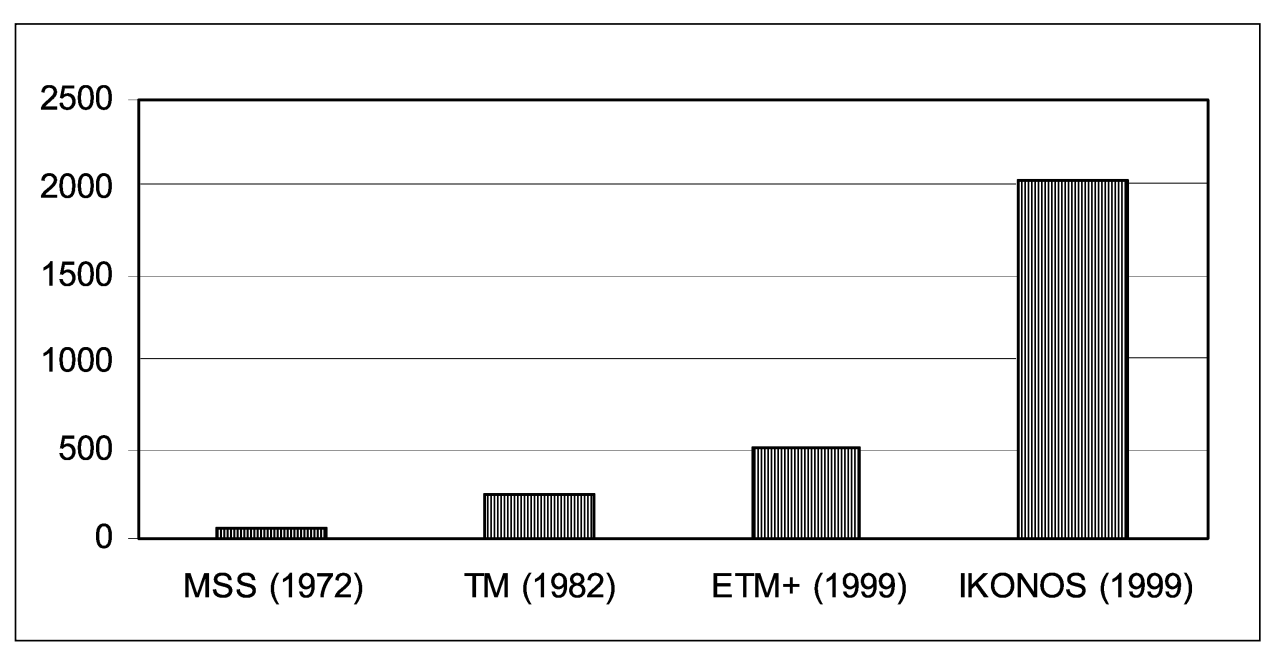

Fig. 1. The increase in the radiometric resolution of satellite imaging systems, expressed by the digital number of pixel brightness levels.

also creates a situation in which quantity translates into quality and in which spatial data of a new quality are created.

Data technology suited for the dissemination of large amounts of data about the environment, and the development of computer appliances and software, contributed to the origination of global information systems - the key ingredient of geoinformatics.

The discipline, which is currently called geoinformatics, emerged several decades ago. How is it being perceived in Poland?

For J. Michalak (http://netgis.geo.uw.edu.pl), a geologist, "geomatics [geoinformatics] is a field of science [and technology] concerned with the issues of the acquisition, collection, management, analysis, interpretation, transfer and utilization of geospatial [spatial, geographic] information, that is, information regarding the Earth." This expert cautions that one should adopt a skeptical stance towards any assertions regarding the emergence of new scientific disciplines and states that "...there is much evidence which indicates that we are dealing with a new discipline, which has formed in the interdisciplinary problem area concerned with geographical information systems, at the crossroads of informatics and what is generally conceived of as earth sciences. The discipline called geomatics [by him] has its own range of questions to answer, its own methods of investigation and its own way of applying its findings" (Fig. 2). He is of the opinion that the dominance of applied research over investigative research, what is often inherent in new disciplines, is not conducive to the development of the latter. He notes this in reference to the geological sciences. One could also say the same of geography, which renounced its field of research to other disciplines, without much of an argument. Only recently has the need to compensate for this deficit been 
seriously considered. By that I mean, among other things, the creation of a geoinformatics specialization within the geography major area of study at Adam Mickiewicz University, starting from the first year of study.

J. Michalak considers the term "geomatics" to be interchangeable with "geoinformatics." The discussion is not yet over as to which is the correct label to be used for this new discipline, and most likely it is never going to end. Personally, and not solely so, I tend to lean more towards "geoinformatics," as it is the term which is more easily understood, and much better at conveying the essence of spatial research focusing on informatics.

In Poland, in 2001, two panel sessions of the Polish Academy of Arts and Sciences Geoinformatics Committee were devoted to this terminological query.

And so, Professor J. Kotlarczyk (2001) - a geologist and Chair of the Polish Academy of Arts and Sciences Geoinformatics Committee - noticed at the time that abroad disparate terms are being used as well. He stated that "...the term geoinformatics originated in the last few decades of the $20^{\text {th }}$ century, as the result of the integration of three disciplines: photogrammetry, remote sensing and geographic information systems." He also notes a number of facts associated with the use of the term "geomatics." The term was used in Canada at Laval University to describe the integration of the above mentioned disciplines. The Canadian Ministry of Natural Resources changed the name of its Department of Geodetic Surveying, Mapping Services and Remote Sensing to GEOMATICS CANADA. The periodical published by "the Canadian Institute of Surveys and Mapping is currently called 'GEOMATICA.' The periodical defines 'geomatics' as '...a discipline of science and technology, which by using a systemic approach, integrates all methods for the gathering and shaping of spatially oriented data, used in the process of mining for and the management of spatially linked information." "

In Europe, it is the term "geoinformatics" that prevails more; it was used in the Netherlands in 1991, where at the famous ITC (International Institute for Aerospace Survey and Earth Sciences), the divisions of Aerial Data Collection and Photogrammetry; Image and Remote Sensing Data Processing; Informatics and Computer Science Applications; and the Department of Cartography, were incorporated to create the GEOINFORMATICS DEPARTMENT.

In Sweden the term "geoinformatics," is also used and is defined as "the science and technology used for the gathering, management, analysis and presentation of geographic and other spatially-defined data."

But let's return to Polish issues. J. Jachimski (2001), a specialist in the area of photogrammetry and remote sensing, understands the concept of "geoinformatics" as "...the science of the gathering, processing and dissemination of information which is spatially defined within the Earth's system."

Understanding the complexity and controversial nature of many terminological and conceptual questions, W. Pachelski (2001), a geodesist, quotes the definition of the concept "geoinformatics," as it stands in accordance with the ISO 19104 standard: the scientific discipline dealing with the 


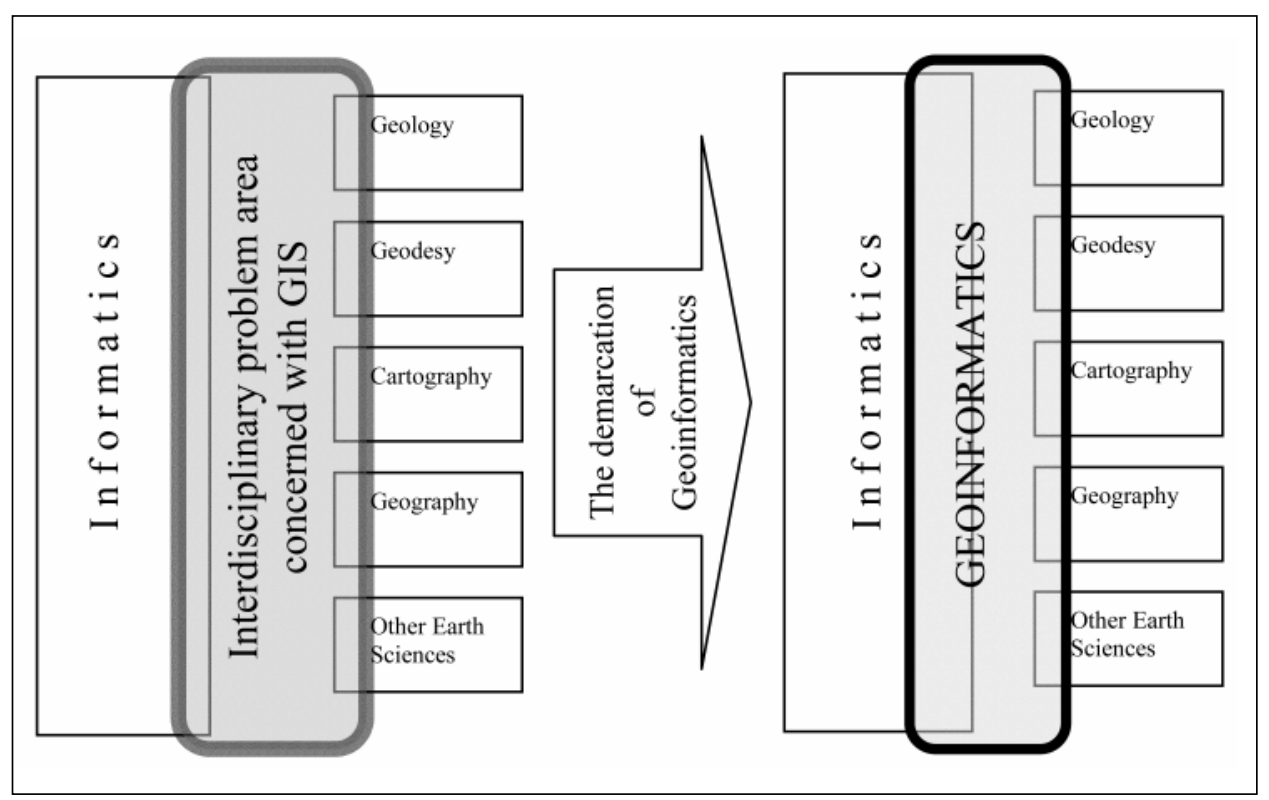

Fig. 2. J. Michalak's conceptualization of geoinformatics.

collection, dissemination, storage, analysis, processing and presentation of geographic data or geographic information.

S.W. Aleksandrowicz (2001), a geologist, considers "geoinformatics" to be a good field for collaboration between specialists engaged in different, mutually dependent and complementary disciplines. From a semantic point of view, geoinformatics can be understood as the union of informatics and the Earth sciences.

Taking a stand in this discussion, I (Olędzki, 2001a) made a statement, fragments of which I will quote here. It needs to be pointed out here that the term "geoinformation" has been functioning in the field of remote sensing since the mid-1970s. It was used in the description of the way in which satellite images are used to study the Earth and the environment, in the general sense. The development of science and technology, especially in the areas of satellite remote sensing, informatics and other fields related to it, was accelerated by the development of geographic information systems (GIS), and resulted in the emergence of a new branch of learning and methodology, which came to be called "geoinformatics." From the geographical point of view, it is a new scientific discipline focused on geographical space; it incorporates remote sensing and photogrammetry, some branches of geodesy, a number of disciplines with the prefix "geo," and some branches of cartography. Geoinformatics forms a common ground for many of the earth sciences to exchange theoretical and methodical ideas. One should assume that a whole series of sub-discipline denominations, referring to more narrow specializations are 


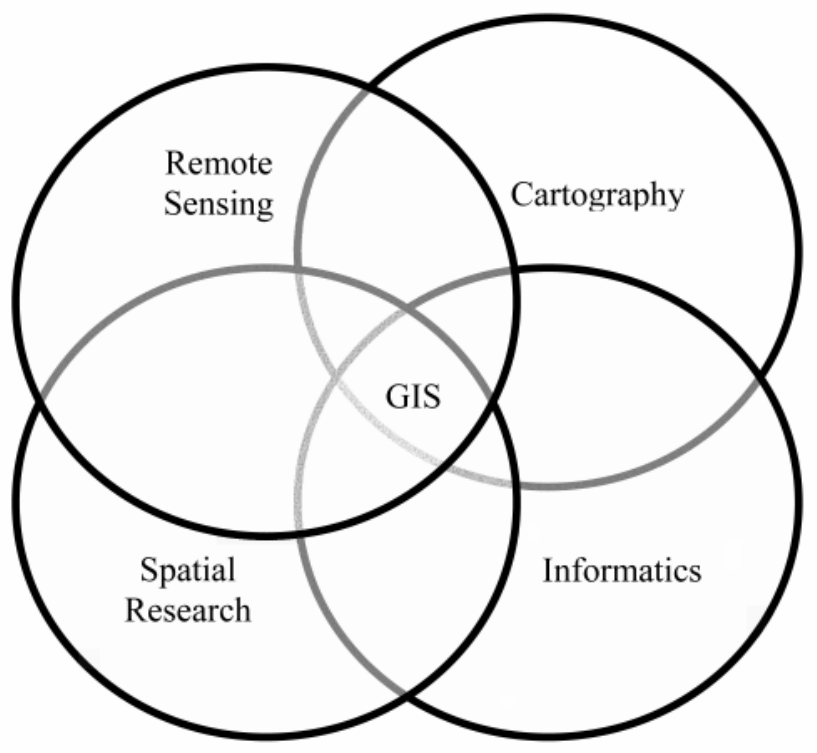

Fig. 3. W. Widacki's conceptualization of geoinformatics, 2001.

encompassed by the term geoinformatics. In 2001, building on these assumptions, I organized a symposium in Wysowa (Małopolskie Voivodship, Poland), with the idea of integrating the above mentioned disciplines, under the motto: Geoinformatics - an integrated spatial research tool. The idea of a joint meeting for specialists who are all involved in geoinformatics met with great interest. A second meeting under the same motto took place in 2003 in Wrocław and Polanica, and a third one is planed for 2005 in Warsaw.

From the definitions and points of view quoted, the conception of geoinformatics which seems to appear is that of a field integrating many earth sciences.

How could the organization of this integration process be conceptualized? The integration could take place according to the diagrams presented in Figs. $2-4$.

From the analysis of various strategies, it is evident that a key tool in the practice of "geoinformatics" seems to be software designed for the processing of huge amounts of data, collections of which have come to be commonly called "systems" - hence "geographic information systems" (GIS). W. Widacki (2001), a geographer at the Jagiellonian University, sees them as the focus of attention in numerous scientific disciplines (Fig. 3).

Should "Geography" be concerned with geoinformatics? Yes, without a doubt. This gives geography new opportunities in precise spatial phenomena analysis, dynamic analyses and in identifying relationships between various components. The use of remote sensing data in such research, takes to another level those areas of knowledge, in which there nevertheless still is 


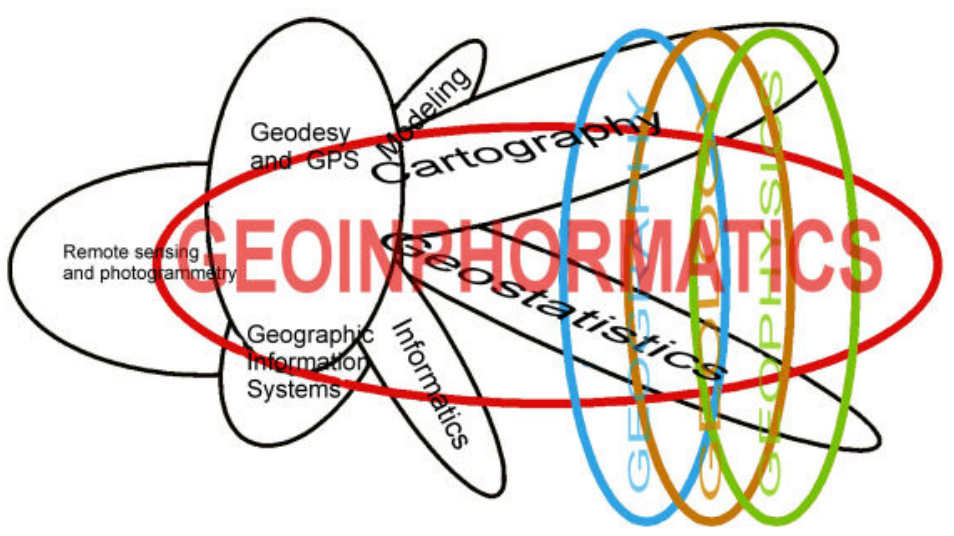

Fig. 4. The author's conceptualization of geoinformatics.

a scarcity of reliable materials. It enables the current monitoring of those phenomena which can't be investigated and estimated in any other way, as well as for the modeling of spatial (geographical) phenomena. From a geographer's point of view, geoinformatics is a discipline integrating various earth sciences, various methods of data collection and presentation, pertinent to spatial phenomena (Fig. 4).

Since 1996 many studies, in which remote sensing data were integrated with data obtained by other methods, have been performed at the Laboratory of Remote Sensing of the Environment at the University of Warsaw. This has made possible the dynamic representation of environmental phenomena, such as changes in landscape composition resulting from various kinds of human activity (Błach, 1998; 2002). It has also brought about the acquisition of qualitatively new and precise knowledge about the quantitative characteristics of the qualitative links and dependencies existing between plant communities and abiotic environmental components. The latter studies have revealed their dialectical character, relying on the shift from general qualitative thematic information to precise quantitative characterization and the description of spatial relationships, expressed hierarchically (Zagajewski, 2002). Also, numerous studies were conducted showing changes in the spatial management of protected regions (Hościło, 2001; Kardaś, 2000; Olędzki, $2001 b ; 2001 c$ ) and in the structure of the environment (Hernik, 1998; Oledz$\mathrm{ki}, 2001)$. Studio projects focused on creating and supplying environmental databases with data by means of remote sensing have also been performed (Drelich, 2000; Szewczykowski, 2002). Other studies also carried out were focused on the integration of remote sensing and geological data by the creation of detailed geomorphological maps (Wołk-Musiał, Zagajewski, 2001). This type of research was made possible by advanced geoinformatics software.

The research contributed to the establishment of a new teaching program (leading to a master's degree) in the new major subject of geoinformatics, at 
Warsaw University's Faculty of Geography and Regional Studies. Its basis consists of remote sensing (in the general sense of the word - including digital image processing), GIS software, geodesy, cartography, geostatistics, modeling and programming, and relational databases.

Geoinformatical questions are the focus of many international and domestic symposia. Many periodicals are devoted to the subject matter as well. In Poland, the publication specialising in the subject is Geoinformatica Poloni$c a$, put out by the Polish Academy of Arts and Sciences Geoinformatics Committee. A periodical with a 40-year history, formerly Photo Interpretation in Geography, Problems of Telegeoinformation, now Remote Sensing of the Environment, is published under the auspices of the Polish Geographic Society. The critical analyses presented there are conducted based on remote sensing data obtained by using global information system tools.

\section{REFERENCES}

Aleksandrowicz S., 2001, Dyskusja panelowa poświęcona zagadnieniom terminologicznym geoinformatyki [Panel discussion devoted to matters of terminology in geoinformatics; in Polish], Geoinformatica Polonica, No. 3, 57-79, Kraków.

Błach B., 1998, Wpływ czynników antropogenicznych na zmiany struktury krajobrazu [The influence of anthropogenic factors upon the structure of the landscape; in Polish], Fotointerpretacja $w$ geografii, problemy telegeoinformacji, V, 28, 52-66, Warszawa.

Błach B., 2002, Zmiany pokrycia terenu w wybranych gminach Beskidów $w$ II połowie XX wie$k u$, na podstawie zdjęć lotniczych [Changes in land cover in selected districts of the Beskidy region in the second part of the 20th century, as seen in aerial photographs; in Polish]. Unpublished doctoral dissertation. Dr. J.R. Olędzki, advisor. Remote Sensing of the Environment Laboratory, Faculty of Geography and Regional Studies, Warsaw University, 250 p., Warszawa.

Drelich I., 2000, Informacja teledetekcyjna w zasilaniu baz danych o obszarach chronionych Euroregionu Karpackiego [The role of remote sensing in supplying information to databases focused on the protected regions of the Carpathian Euroregion; in Polish], Fotointerpretacja $w$ geografii, problemy telegeoinformacji, V, 31, 46-81, Warszawa.

Hernik A., 1998, Badania porównawcze struktury krajobrazu [Comparative studies of landscape structure; in Polish], Fotointerpretacja $w$ geografii, problemy telegeoinformacji, V, 28, $29-51$, Warszawa.

Hościło A., 2001, Zmiany użytkowania ziemi fragmentu Narwiańskiego Parku Narodowego w latach 1956-1999 [Changes in land use in a section of the Narew National Park from 1956 to 1999; in Polish], Teledetekcja środowiska, V, 32, 106 -117, Warszawa.

Jachimski J., 2001, Dyskusja panelowa poświęcona zagadnieniom terminologicznym geoinformatyki [Panel discussion devoted to matters of terminology in geoinformatics; in Polish], Geoinformatyka Polonica, No. 3, 57-79, Kraków.

Kardaś P., 2000, Zastosowanie telegeoinformacji w badaniach zmian pokrycia terenu Magurskiego Parku Narodowego w latach 1935-1999 [The application of telegeoinformation in studies of land cover in the Magurian National Park conducted between 1935 and 1999; in Polish], Fotointerpretacja w geografii, problemy telegeoinformacji, V, 31, 82-90, Warszawa.

Kotlarczyk J., 2001, Dyskusja panelowa poświęcona zagadnieniom terminologicznym geoinformatyki [Panel discussion devoted to matters of terminology in geoinformatics; in Polish], Geoinformatica Polonica, No. 3, 57-79, Kraków.

Michalak J., Geomatyka (geoinformatyka) - czy nowa dyscyplina? [Geomatics (geoinformatics) - Is it a new line of science?; in Polish], NetGIS, http://netgis.geo.uw.edu.pl. 
Olędzki J.R., 2001, Regiony fotomorficzne Polski [The photomorphic regions of Poland; in Polish], AKAPIT-DTP, Warszawa.

Olędzki J.R., 2001a, Dyskusja panelowa poświęcona zagadnieniom terminologicznym geoinformatyki [Panel discussion devoted to matters of terminology in geoinformatics; in Polish], Geoinformatica Polonica, No. 3, 57-79, Kraków.

Olę d zki J.R., 2001b, Użytkowanie ziemi na terenie Wigierskiego Parku Narodowego w latach $1969-1997$ [Land use within the confines of the Wigry National Park from 1969 to 1997; in Polish], [in:] A. Richling, J. Solon (eds), Z badań nad strukturq i funkcjonowaniem Wigierskiego Parku Narodowego (Selected studies on the structure and functioning of the Wigry National Park), Faculty of Geography and Regional Studies, Warsaw University, 263-266, Warszawa.

Olędzki J.R 2001c, Analiza użytkowania ziemi w rejonie rezerwatu "Białe Ługi" [Land use analysis of the "Białe Ługi" reserve area; in Polish], [in:] Rezerwat torfowiskowy "Białe Ługi" [The "Białe Ługi” peat-bog reserve; in Polish], S. Żur e k (ed.), Homini Publishing, $117-120$, Bydgoszcz.

Pachelski W., 2001, Dyskusja panelowa poświęcona zagadnieniom terminologicznym geoinformatyki [Panel discussion devoted to matters of terminology in geoinformatics; in Polish], Geoinformatica Polonica, No. 3, 57-79, Kraków.

S zewczykowski M., 2002, Opracowanie bazy danych do analizy środowiska przyrodniczego okolic Etku [Database preparation for the analysis of the natural environment in the Ełk area; in Polish]. Manuscript, Remote Sensing of the Environment Laboratory, The Faculty of Geography and Regional Studies, Warsaw University, 111 p., Warszawa.

Widacki W., 2001, Systemy informacji geograficznej i ich rola w naukach przestrzennych [Geographic information systems and their role in spatial research; in Polish], Geoinformatica Polonica, No. 3, 47-56, Kraków.

Wołk-Musiał E., Zagajew ski B., 2000, Analiza geomorfologiczna terenu z zastosowaniem systemów informacji geograficznej [Geomorphological terrain analysis with the use of geographic information systems; in Polish], Fotointerpretacja $w$ geografii, problemy telegeoinformacji, V, 31, 137-142, Warszawa.

Zagajew ski B., 2002, Zastosowanie geoinformacji w badaniach wptywu abiotycznych komponentów środowiska na rozmieszczenie roślinności w Narwiańskim Parku Narodowym $i$ jego otulinie [Geoinformation applied to the study of the abiotic environmental components' influence on the vegetation distribution in the Narwia National Park and its buffer zone; in Polish]. Unpublished doctoral dissertation. Dr. J.R. Olędzki, advisor. Remote Sensing of the Environment Laboratory, Faculty of Geography and Regional Studies, Warsaw University, 137 p., Warszawa.

English translation: Joanna M. Kwiatowska 